\title{
HUBUNGAN SIKAP KERJA TERHADAP KELUHAN MUSCULOSKELETAL PADA PEKERJA HOME INDUSTRY DI SURABAYA
}

\section{THE RELATION OF WORK ATTITUDE TO MUSCULOSKELETAL DISORDERS AT HOME INDUSTRY WORKERS IN SURABAYA}

\author{
Fara Lizenda Permatasari, Noeroel Widajati \\ Departemen Keselamatan dan Kesehatan Kerja \\ Fakultas Kesehatan Masyarakat, Universitas Airlangga \\ E-mail: faralizenda30@yahoo.com
}

\begin{abstract}
Musculoskeletal disorders were occurred in any workers, one of them are informal sector worker such as home industry in Surabaya. Works were still done manually in home industry can cause Musculoskeletal disorders (MSDs). Some of the causes of musculoskeletal disorders were work attitude. The purpose of this study was to determine the correlation between work attitude against musculoskeletal disorders. This research was an observational descriptive research with cross sectional design. Work attitude were measured using RULA (Rapid Upper Limb Assessment) The samples of this study were 20 workers who work in home industry. Data were analyzed using cross tabulation and correlation value Phi and Creamers $V$. The results showed that there were correlations between the work attitude with musculoskeletal disorders. Work attitude had a moderate correlation with correlation value 0.394. The conclusion of this study was work attitude had correlation with musculoskeletal disorders on home industry workers in Surabaya. High-risk work attitude can occur by poor work station condition.
\end{abstract}

Keywords: home industry, musculoskeletal disorders, work attitude

\begin{abstract}
ABSTRAK
Keluhan musculoskeletal dapat terjadi pada pekerja apa saja, salah satunya adalah pada pekerja sektor informal seperti pada home industri yang ada di Surabaya. Pekerjaan yang masih dilakukan secara manual pada home industri berisiko terhadap keluhan musculoskeletal. Beberapa penyebab terjadinya keluhan musculoskeletal yaitu karena faktor pekerjaan seperti beban kerja, sikap kerja dan stasiun kerja. Tujuan dari penelitian ini untuk mengetahui hubungan antara sikap kerja terhadap keluhan musculoskeletal. Penelitian ini merupakan penelitian observasional deskriptif dengan menggunakan pendekatan cross sectional. Cara penilaian sikap kerja menggunakan Rapid Upper Limb Assessment (RULA). Jumlah sampel pada penelitian ini adalah seluruh pekerja home industri sebanyak 20 orang. Analisis data yang digunakan adalah tabulasi silang dan nilai korelasi Phi and Creamers V. Hasil penelitian menunjukkan tingkat korelasi antara sikap kerja dengan keluhan musculoskeletal. Sikap kerja memiliki korelasi sedang dengan nilai 0,394. Kesimpulan dari penelitian ini adalah sikap kerja memiliki hubungan dengan keluhan musculoskeletal pada pekerja home industri di Surabaya. Sikap kerja dengan risiko tinggi dapat terjadi karena kondisi stasiun kerja yang tidak baik.
\end{abstract}

Kata kunci: home industry, keluhan musculoskeletal, sikap kerja

\section{PENDAHULUAN}

Suma'mur (2001) menyatakan, "keselamatan kerja adalah rangkaian usaha untuk menciptakan suasana kerja yang aman dan tentram bagi para karyawan yang bekerja di perusahaan yang bersangkutan." Penerapan ergonomi pada tempat kerja merupakan salah satu upaya keselamatan dan kesehatan kerja. Istilah ergonomi (Ergon $=$ Kerja dan Nomos $=$ Hukum alam) berasal dari bahasa latin. Ergonomi disebut sebagai human factor yang artinya penyesuaian manusia dengan suasana kerjanya, selain itu ergonomi juga erat hubungannya dengan efisiensi, optimasi dan kenyamanan manusia yang berada baik di tempat kerja, tempat rekreasi maupun di rumah. 
Ergonomi yang diterapkan umumnya dalam bentuk perancangan ulang (re-design) dan perancangan bangun (design). Perancangan yang dimaksud terbagi menjadi dua yaitu hardware yang meliputi peralatan kerja, conveyor, dan lainnya. Software seperti jam istirahat, rotasi kerja, dan lainnya.

Melakukan suatu pekerjaan tidak luput dari adanya risiko kecelakaan maupun penyakit akibat kerja yang dapat terjadi di tempat kerja. Penyakit akibat kerja dapat disebabkan karena berbagai faktor salah satunya karena tempat kerja dan juga gaya hidup seseorang.

Angka kecelakaan kerja dan penyakit akibat kerja di Indonesia tergolong tinggi. Menurut catatan Direktorat Jenderal Pembinaan Pengawasan Ketenagakerjaan (Ditjen PPK) pada Triwulan II Tahun 2014 kasus kecelakaan kerja di Indonesia berjumlah 17.858 kasus. Dari jumlah kasus tersebut, sebanyak 306 orang pekerja dinyatakan meninggal dunia, 343 orang pekerja mengalami cacat, 7.355 orang pekerja sementara tidak mampu bekerja, dan 10.101 orang pekerja dinyatakan sembuh. Wacana tersebut membuktikan bahwa angka kecelakaan kerja di Indonesia tergolong tinggi.

Penyakit akibat kerja yakni suatu penyakit yang dapat terjadi karena suatu pekerjaan, baik yang disebabkan oleh keadaan yang tidak ergonomis seperti sikap kerja maupun lingkungan kerjanya. Keluhan musculoskeletal merupakan salah satu contoh penyakit akibat kerja yang dapat timbul di tempat kerja. Keluhan tersebut terjadi pada bagian otot skeletal dimana keluhan dapat dirasakan dari keluhan otot yang ringan hingga keluhan otot yang berat. Keluhan otot tersebut disebabkan oleh pekerjaan manual handling.

Menurut Nurmianto (1998) pekerjaan manual handling yakni pekerjaan pengangkatan beban seperti aktivitas mendorong, mengangkat, meraih, menurunkan, dan menarik. Pekerjaan manual handling dilakukan untuk memindahkan beban dari satu lokasi menuju lokasi lainnya.

Studi tentang musculoskeletal (MSDs) telah banyak dilakukan pada berbagai industri, dimana hasil penelitian menunjukkan bahwa terdapat bagian otot yang sering mengalami keluhan. Bagian otot tersebut seperti otot-otot skeletal atau biasa disebut dengan otot rangka yang meliputi otot leher, lengan, tangan, jari, punggung, pinggang, dan otot bagian bawah.

Keluhan musculoskeletal di suatu industri kurang mendapat perhatian dari pengusaha atau pemilik.
Masih banyak ditemui di perusahaan-perusahaan pengusaha atau pemilik belum memahami faktor risiko keluhan musculoskeletal sehingga seringkali keluhan musculoskeletal tidak disadari.

Laporan Depkes RI yang dikutip oleh Ulfah (2014), studi yang dilakukan pada 482 pekerja di 12 kabupaten/kota di Indonesia menunjukkan bahwa umumnya penyakit yang dijumpai di lapangan pekerjaan adalah musculoskeletal disorders (MSDs) yaitu sebesar 16\%. Menurut The Bureau of Labor Statistics (BLS) pada tahun 2011 MSDs menyumbang 33\% kasus cedera akibat kerja dan penyakit akibat kerja dengan jumlah kasus sebanyak 387.820 (Tarwaka, 2014).

Menurut OHSA (2000) keluhan musculoskeletal adalah gangguan atau cidera pada jaringan lunak seperti otot, tendon, sendi, ligamen serta sistem syaraf. Paling sering terjadi pada bagian lengan dan punggung. Menurut Tarwaka (2014) menyebutkan bahwa keluhan musculoskeletal merupakan keluhan yang terjadi pada otot rangka yang dialami oleh seseorang mulai dari keluhan yang ringan sampai dengan keluhan yang sangat berat.

Penelitian yang dilakukan oleh Sumiati (2007) pada 9.482 pekerja menemukan gangguan kesehatan yang paling banyak dialami oleh pekerja yaitu gangguan musculoskeletal sebanyak 16\%.

Keluhan musculoskeletal terjadi karena adanya pembebanan yang cukup berat dan berulang (repetitif) yang menyebabkan otot mengalami kontraksi secara berlebihan sehingga melebihi kekuatan otot maksimum. Otot mengalami kontraksi yang melebihi kekuatan maksimumnya maka dapat menghambat asupan oksigen ke otot sehingga dapat menghambat metabolisme karbohidrat. Metabolisme karbohidrat terganggu dapat menyebabkan penimbunan asam laktat pada otot yang berakibat pada timbulnya rasa nyeri pada otot (Tarwaka, 2004; Suma'mur, 1982; Grandjean, 1993).

Keluhan musculoskeletal terbagi menjadi beberapa jenis seperti, keluhan leher. Keluhan pada leher umum terjadi pada saat bekerja. Keluhan tersebut biasanya berupa pegal bahkan nyeri. Nyeri pada leher biasanya disebabkan karena pekerjaan yang dilakukan dengan posisi duduk secara terus menerus. Salah satu keluhan leher yaitu Tension Neck Syndrome.

Keluhan selanjutnya yaitu bahu yang ditandai dengan rasa nyeri pada bahu terutama gerakan yang melibatkan bahu; yang ketiga yaitu keluhan pinggang, merupakan keluhan yang paling banyak dialami oleh pekerja. Keluhan ini biasa disebut 
dengan low back pain. Gejala yang biasa dirasakan seperti nyeri bahkan dapat menyebabkan kelemahan pada tungkai; yang keempat yakni keluhan siku, dapat terjadi karena terdapat gerakan berulang pada tangan yang melibatkan ekstensi pada siku dan aktivitas flexion siklis.

Keluhan yang terakhir yaitu keluhan pergelangan tangan dan telapak tangan, biasa disebut dengan CTS (Carpal Tunnel Syndrome) ditandai dengan gejala mati rasa pada jari. Terdapat keluhan pergelangan lainnya yaitu tendinitis yang terjadi karena pekerjaan dengan postur yang janggal selama terus menerus yang menyebabkan inflamasi pada tendon.

Istilah keluhan musculoskeletal di setiap negara berbeda-beda. Pada negara Jepang lebih dikenal dengan sebutan Occupational Cervicobrachial Disorder. Negara Amerika lebih dikenal dengan sebutan Cumulative Trauma Disorders (CTDs). Istilah lain selain yang telah disebutkan diatas seperti Neck and Limb Disorders, Repetitive Strain Injuries (RSIs), Overuse Disorders, dsb. (NIOSH, 1993).

Sikap kerja merupakan salah satu penyebab keluhan musculoskeletal. Anies (2014) menyebutkan bahwa sikap kerja terhadap alat kerja berpotensi menyebabkan gangguan kesehatan. Sikap kerja pada saat bekerja yang tidak baik dapat menyebabkan gangguan seperti nyeri, kelelahan, bahkan kecelakaan. Sikap kerja baik duduk maupun berdiri dalam jangka waktu yang panjang juga dapat menyebabkan masalah kesehatan baik dalam jangka pendek maupun jangka panjang.

Sikap kerja yang tidak baik dapat menyebabkan bagian tubuh bergerak menjauhi tubuh. Seperti punggung yang terlalu membungkuk. Semakin jauh posisi tubuh dari pusat gravitasi tubuh semakin besar risiko mengalami keluhan musculoskeletal.

Penelitian oleh Ikrimah (2010) menyebutkan bahwa diketahui faktor yang berhubungan dengan keluhan musculoskeletal salah satunya adalah sikap kerja yang memiliki $P$-value sebesar 0,029 dengan $\mathrm{OR}=0,205$ yang artinya pekerja yang memiliki risiko pekerjaan tinggi berpeluang 0,205 kali mengalami keluhan musculoskeletal dibanding dengan pekerja yang memiliki risiko pekerjaan sedang atau rendah.

Keluhan otot skeletal dapat dibedakan menjadi keluhan sementara dan keluhan menetap. Keluhan sementara terjadi ketika otot menerima beban yang statis, namun keluhan tersebut akan segera hilang jika pembebanan sudah dihentikan. Sedangkan keluhan yang menetap walaupun pembebanan yang diterima sudah dihentikan, keluhannya akan tetap berlanjut.

Akobundu (2008) menyebutkan bahwa gejala awal keluhan musculoskeletal yakni berupa rasa sakit pada otot yang menandakan bahwa otot perlu pemulihan atau istirahat. Menurut Grandjean (1993) dan Akobundu (2008) dalam Maijunidah (2010) juga menyebutkan bahwa gejala keluhan musculoskeletal terbagi menjadi beberapa tahap, yakni tahap pertama atau awal gejalanya seperti pegal, dan keluhan pada bagian tubuh tertentu. tahap selanjutnya yakni tahap kedua atau intermediate, gejala yang timbul seperti rasa sakit setelah melakukan pekerjaan dalam sehari, selain itu juga dapat mengganggu kualitas tidur pekerja jika sudah mencapai tahap ini.

Tahap ketiga atau akhir, gejalanya seperti rasa sakit dan lelah pada bagian tubuh tertentu. Gejala tersebut tidak hilang walaupun telah beristirahat, gejala tersebut dapat timbul lagi ketika melakukan pekerjaan yang berulang.

Dampak keluhan musculoskeletal menurut Bird dan Germain (2005) yakni seperti hilangnya waktu kerja, menurunkan produktivitas kerja, menurunkan kewaspadaan, meningkatkan risiko terjadinya kecelakaan, jika keluhan sudah mencapai tahap akhir maka membutuhkan biaya yang tinggi untuk pemulihannya. Keluhan musculoskeletal membutuhkan waktu dan berbagai tahapan untuk dapat menimbulkan rasa sakit pada bagian tubuh tertentu.

Keluhan musculoskeletal dapat terjadi baik pada sektor formal maupun sektor informal. Menurut Alma (2001) menjelaskan bahwa sektor informal merupakan manifestasi lapangan pekerjaan yang berskala kecil dengan tujuan mendapat pendapatan tanpa adanya keuntungan. Pekerja pada sektor informal tidak harus memiliki keahlian atau keterampilan khusus seperti pekerja pada sektor formal. Pekerja sektor informal berasal dari berbagai golongan.

Pada sektor formal pengusaha atau pengurus memiliki kewajiban untuk menjamin kesejahteraan pekerjanya, sedangkan pada sektor informal tidak ada pihak tertentu baik pengurus atau pengusaha yang menjamin kesejahteraan pekerjanya. Pada sektor informal pekerja bertanggung jawab terhadap kesejahteraan nya sendiri. Kesejahteraan pekerja yang dimaksud yakni pekerja mendapatkan jaminan rasa aman dan nyaman selama bekerja seperti terhindar dari kecelakaan akibat kerja maupun penyakit akibat kerja. 
Penelitian yang dilakukan oleh Elza (2012) menunjukkan pada sektor informal pengrajin songket tradisional di Sumatera Barat memiliki risiko ergonomi yang tinggi berdasarkan penilaian dengan metode RULA yang dilakukan. Hasil penelitian menunjukkan keluhan musculoskeletal yang paling sering dialami oleh pekerja yakni pada bagian punggung sebesar $80 \%$, kemudian keluhan pada bagian bahu sebelah kanan sebesar $74 \%$, dan yang terakhir keluhan pada pinggang sebesar $72 \%$.

Menurut Riyadina (2008) penelitian yang melibatkan 800 orang pekerja pada 8 sektor informal menyebutkan terdapat gangguan musculoskeletal yang salah satunya dialami oleh perajin sepatu di Bogor yaitu sebanyak $14,9 \%$, kemudian pada perajin wayang kulit di Yogyakarta sebanyak 21\%, dan lainnya.

Sedangkan berdasar penelitian yang dilakukan oleh Evelina (2012) pada pekerja pengrajin sepatu Bogor. Di dalam penelitian yang dilakukan menunjukkan bahwa terdapat risiko ergonomi yang tinggi berdasarkan hasil penilaian dengan metode REBA. Keluhan musculoskeletal paling banyak ditemukan pada aktivitas penjahitan dan pembuatan pola. Keluhan terjadi pada bagian pinggang dan leher atas yakni sebesar 77,4\%.

Home industry yang ada di Surabaya merupakan salah satu contoh dari sektor informal. Home industry ini berdiri sejak tahun 2005 hingga sekarang. Pada home industry ini menjual makanan ringan seperti sumpia dan bidaran. Dalam sehari home industry ini dapat memproduksi $400 \mathrm{~kg}$ makanan ringan bidaran dan $200 \mathrm{~kg}$ makanan ringan sumpia. Seluruh kegiatan yang ada di home industry ini masih dilakukan secara manual seperti membuat kulit sumpia, membuat adonan bidaran, menggulung sumpia, menggoreng makanan ringan, dan juga packing. Hal tersebut tidak menutup kemungkinan pekerja yang bekerja di home industry di Surabaya ini berisiko mengalami keluhan musculoskeletal.

Pemaparan tersebut di atas, menjadi latar belakang peneliti melakukan penelitian terkait hubungan faktor pekerjaan dengan keluhan subjektif musculoskeletal pada pekerja home industry di Surabaya. Diharapkan setelah melakukan penelitian ini dapat mempelajari hubungan antara faktor pekerjaan dengan keluhan subjektif musculoskeletal pada pekerja Home Industry di Surabaya.

\section{METODE}

Penelitian ini merupakan penelitian observational karena peneliti hanya melakukan pengamatan tanpa memberikan perlakuan terhadap responden. Berdasarkan cara analisis data, penelitian ini merupakan penelitian deskriptif karena penelitian ini memberikan suatu gambaran keadaan dengan cara mendeskripsikan sejumlah variabel yang berhubungan terhadap suatu akibat. Studi penelitian menggunakan pendekatan cross sectional karena penelitian ini dilakukan pada waktu yang bersamaan mulai dari proses pengambilan data hingga pengukuran variabel-variabelnya.

Penelitian dilakukan pada home industri yang terletak di JL. Rangkah VII No. 91, Surabaya. Penelitian dilaksanakan pada Juli 2017. Data primer diperoleh dengan penyebaran kuesioner, pengukuran, observasi dan wawancara informal. Data primer yang dikumpulkan yaitu data responden, sikap kerja, dan keluhan musculoskeletal. Responden dalam penelitian ini adalah seluruh pekerja pada home industri di Surabaya yang berjumlah 20 orang.

Variabel dependen dalam penelitian ini adalah keluhan musculoskeletal (MSDs) yang akan diukur dengan menggunakan kuesioner Nordic Body Map (NBM). Variabel independen dari penelitian ini adalah faktor pekerjaan yang akan diukur dengan menggunakan lembar observasi Rapid Upper Limb Assessment (RULA).

Data hasil penelitian yang diperoleh akan dikumpulkan dan kemudian dianalisis untuk mengetahui hubungan antar variabel. Teknik analisis data dalam penelitian ini disajikan dengan menggunakan cross tabulation. Untuk melihat kuat hubungan menggunakan nilai korelasi $P h i$ and creamers $V$.

\section{HASIL}

\section{Karakteristik Responden}

Jumlah responden sebanyak 20 orang, berdasarkan tabel 1 menunjukkan bahwa sebagian besar responden berusia 31-40 tahun sebanyak 6 responden $(30 \%)$, sebagian besar memiliki masa kerja antara 1-5 tahun yaitu sebanyak 9 responden (45\%). Sebanyak 11 responden $(55 \%)$ memiliki riwayat penyakit otot dan sendi. 
Tabel 1. Distribusi Karakteristik Responden di Home Inclusing Tahun 2017

\begin{tabular}{|c|c|c|c|}
\hline Variabel & Kategori & Frekuensi & $\begin{array}{c}\text { Persentase } \\
(\%)\end{array}$ \\
\hline \multirow{4}{*}{ Usia } & $\leq 30$ tahun & 5 & 25 \\
\hline & $31-40$ tahun & 6 & 30 \\
\hline & $41-50$ tahun & 5 & 25 \\
\hline & $>50$ tahun & 4 & 20 \\
\hline \multicolumn{2}{|r|}{ Total } & 20 & 100 \\
\hline \multirow{3}{*}{$\begin{array}{l}\text { Masa } \\
\text { Kerja }\end{array}$} & $1-5$ tahun & 9 & 45 \\
\hline & 6-10 tahun & 6 & 30 \\
\hline & $11-15$ tahun & 5 & 25 \\
\hline \multicolumn{2}{|r|}{ Total } & 20 & 100 \\
\hline $\begin{array}{l}\text { Riwayat } \\
\text { Penyakit }\end{array}$ & $\mathrm{Ya}$ & 9 & 45 \\
\hline $\begin{array}{l}\text { Otot dan } \\
\text { Sendi }\end{array}$ & Tidak & 11 & 55 \\
\hline \multicolumn{2}{|c|}{ Total } & 20 & 100 \\
\hline
\end{tabular}

\section{Sikap Kerja}

Sikap kerja responden diukur dengan menggunakan lembar kuesioner Rapid Upper Limb Assessment (RULA) dengan pengukuran secara skoring untuk menentukan kategori risiko yang terdiri dari risiko rendah, risiko sedang, risiko tinggi, dan risiko sangat tinggi. Berdasarkan penelitian yang telah dilakukan didapatkan hasil pada Tabel 2.

Tabel 2 dapat diketahui bahwa dari total 20 responden sebanyak 11 responden (55\%) memiliki sikap kerja dengan risiko sedang, dan sebanyak 9 responden (45\%) memiliki sikap kerja dengan risiko tinggi.

Untuk skor grup A terdiri dari lengan atas, lengan bawah, pergelangan tangan, perputaran pergelangan tangan.

Gambar 2 menunjukkan lengan bawah membentuk sudut $40^{\circ}$. Gambar 3 menunjukkan pergelangan tangan pada posisi netral, namun

Tabel 2. Distribusi Sikap kerja Responden

\begin{tabular}{lcc}
\hline \multicolumn{1}{c}{ Sikap Kerja } & Frekuensi & Persentase (\%) \\
\hline Risiko Sedang & 11 & 55 \\
Risiko Tinggi & 9 & 45 \\
\hline Total & 20 & 100 \\
\hline
\end{tabular}

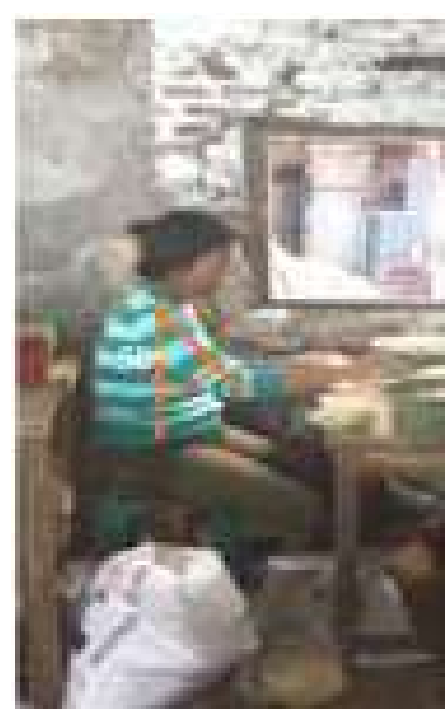

Gambar 1. Skor Lengan Atas.

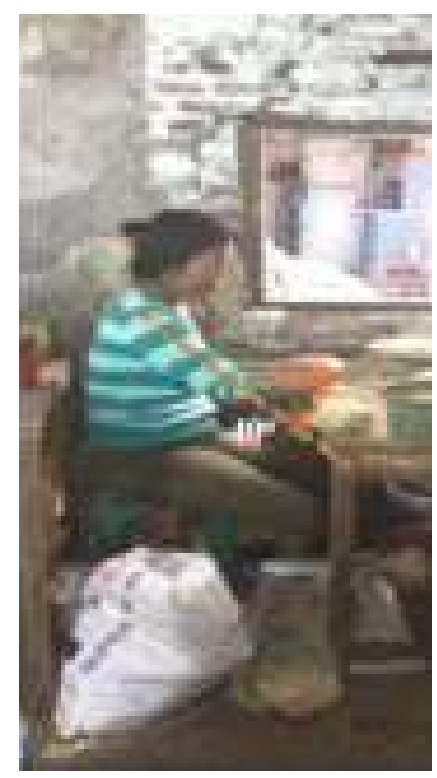

Gambar 2. Skor Lengan Bawah.

pergelangan tangan memuntir. Gambar 4 menunjukkan leher membentuk sudut sebesar $15^{\circ}$. Gambar 5 menunjukkan bahwa badan responden membentuk sudut $15^{\circ}$. Gambar 6 menunjukkan sikap kaki responden, dapat dilihat bahwa responden duduk dengan kedua kaki tertopang dengan baik.

Hasil skor pada tiap bagian tubuh seperti lengan atas, lengan bawah, dan pergelangan tangan kemudian dimasukkan ke dalam tabel skor grup A RULA. Setelah didapatkan skor grup A ditambahkan 


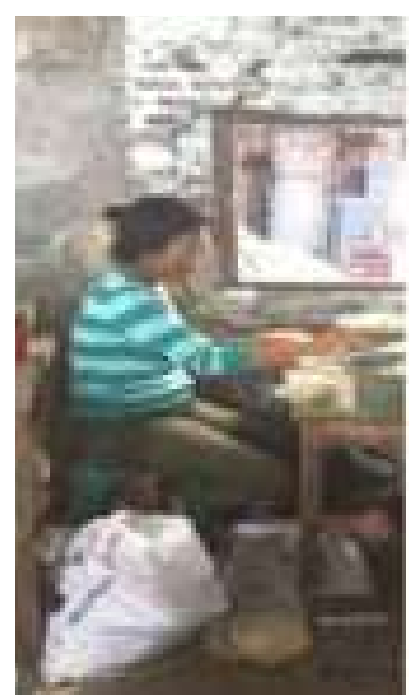

Gambar 3. Skor Pergelangan Tangan.

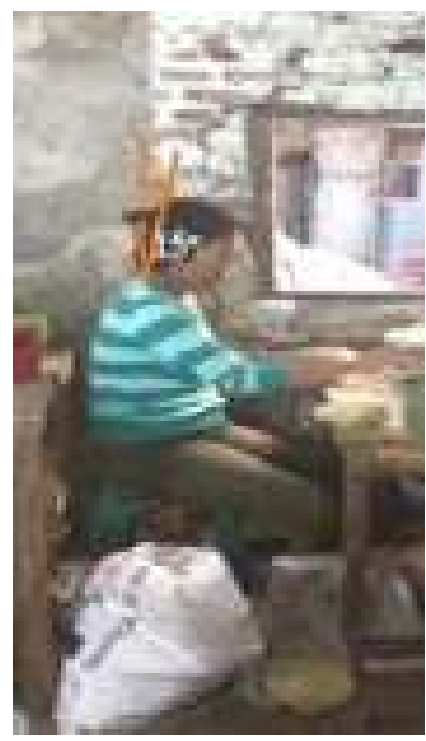

Gambar 4. Skor Leher.

dengan skor pembebanan dan penggunaan otot. Setelah mendapat skor penambahan maka skor grup A menjadi skor $\mathrm{C}$.

Untuk skor grup B terdiri dari leher, badan (trunk), dan kaki. Untuk melihat sikap kerja tersebut dapat dilihat pada Gambar 4.

Setelah diketahui skor tiap bagian tubuh dari grup B maka skor akan dimasukkan ke dalam tabel skor grup B. Setelah diperoleh skor grup B maka ditambah dengan skor pembebanan dan penggunaan otot sama halnya dengan penambahan skor pada

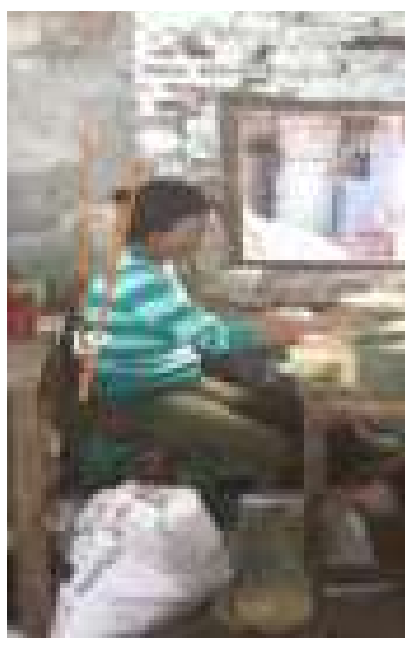

Gambar 5. Skor Badan (Trunk).

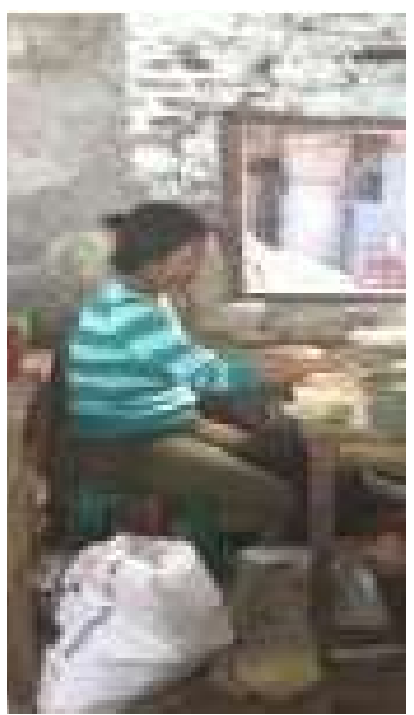

Gambar 6. Skor Kaki.

grup A. Setelah penambahan skor tersebut maka skor B berubah menjadi skor D.

Skor C dan skor D kemudian dimasukkan kedalam tabel grand skor RULA. Skor grand RULA atau skor akhir RULA yang diperoleh akan digunakan untuk menentukan kategori risiko sikap kerja.

Tabel 3 menunjukkan responden dengan sikap kerja kategori risiko sedang artinya memerlukan perbaikan sikap kerja, sedangkan untuk responden dengan kategori sikap kerja risiko tinggi maka diperlukan tindakan segera. 
Tabel 3. Hasil Akhir RULA di Home Industry Tahun 2017

\begin{tabular}{ccc}
\hline Responden & Skor Akhir & Kategori \\
\hline 1 & 6 & Tinggi \\
2 & 4 & Sedang \\
3 & 4 & Sedang \\
4 & 6 & Tinggi \\
5 & 4 & Sedang \\
6 & 3 & Sedang \\
7 & 3 & Sedang \\
8 & 4 & Sedang \\
9 & 5 & Tinggi \\
10 & 5 & Tinggi \\
11 & 5 & Tinggi \\
12 & 4 & Sedang \\
13 & 6 & Tinggi \\
14 & 4 & Sedang \\
15 & 6 & Tinggi \\
16 & 4 & Sedang \\
17 & 5 & Tinggi \\
18 & 5 & Tinggi \\
19 & 5 & Tinggi \\
20 & 5 & Tinggi \\
\hline
\end{tabular}

Tabel 4. Distribusi Keluhan Musculoskeletal di Home Industry Tahun 2017

\begin{tabular}{lcc}
\hline Keluhan MSDs & Frekuensi & Persentase (\%) \\
\hline Sedang & 9 & 45 \\
Tinggi & 11 & 55 \\
\hline Total & 20 & 100 \\
\hline
\end{tabular}

\section{Keluhan Musculoskeletal}

Pengukuran keluhan musculoskeletal diukur dengan menggunakan Nordic Body Map (NBM). Distribusi keluhan musculoskeletal dapat dilihat pada Tabel 4.

Pada Tabel 4 menunjukkan bahwa sebanyak 11 responden (55\%) mengalami keluhan musculoskeletal tingkat tinggi, sedangkan sebanyak 9 responden (45\%) mengalami keluhan musculoskeletal tingkat sedang. Untuk mengetahui skor akhir keluhan musculoskeletal dapat dilihat pada Tabel 5.
Tabel 5. Hasil NBM di Home Industry Tahun 2017

\begin{tabular}{ccc}
\hline Responden & Skor Akhir & Kategori \\
\hline 1 & 22 & Sedang \\
2 & 23 & Sedang \\
3 & 21 & Sedang \\
4 & 22 & Sedang \\
5 & 25 & Sedang \\
6 & 46 & Tinggi \\
7 & 24 & Sedang \\
8 & 44 & Tinggi \\
9 & 44 & Tinggi \\
10 & 24 & Sedang \\
11 & 45 & Tinggi \\
12 & 23 & Sedang \\
13 & 44 & Tinggi \\
14 & 21 & Sedang \\
15 & 45 & Tinggi \\
16 & 42 & Tinggi \\
17 & 43 & Tinggi \\
18 & 42 & Tinggi \\
19 & 43 & Tinggi \\
20 & 45 & Tinggi \\
\hline
\end{tabular}

\section{Hubungan Sikap kerja dengan Keluhan Musculoskeletal}

Dianalisis dengan menggunakan cross tabulation, sehingga didapatkan hasil sesuai pada Tabel 6 yang menunjukkan 11 responden mengalami keluhan Musculoskeletal tingkat tinggi, diantaranya sebanyak 3 responden $(33,3 \%)$ memiliki sikap kerja yang berisiko rendah dan 8 responden $(72,7 \%)$ lainnya memiliki sikap kerja yang berisiko tinggi.

Hasil analisis cross tabulation diperoleh nilai Phi and Creamers $V$ sebesar 0,394 yang berarti korelasi antara sikap kerja dengan keluhan musculoskeletal sedang.

\section{PEMBAHASAN}

\section{Keluhan Musculoskeletal}

Untuk melihat keluhan musculoskeletal responden maka diukur dengan menggunakan Nordic Body Map (NBM). Pengukuran ini dilakukan dengan cara menanyakan kepada responden bagian 
Tabel 6. Hubungan Sikap kerja dengan Keluhan Musculoskeletal di Home Industry Tahun 2017

\begin{tabular}{|c|c|c|c|c|c|}
\hline \multirow{3}{*}{$\begin{array}{l}\text { Sikap } \\
\text { Kerja }\end{array}$} & \multicolumn{4}{|c|}{ Keluhan Musculoskeletal } & \multirow{3}{*}{$\begin{array}{c}\text { Phi and } \\
\text { Creamer's V }\end{array}$} \\
\hline & \multicolumn{2}{|c|}{ Rendah } & \multicolumn{2}{|c|}{ Tinggi } & \\
\hline & $\mathbf{n}$ & $\%$ & $\mathbf{n}$ & $\%$ & \\
\hline $\begin{array}{l}\text { Risiko } \\
\text { rendah }\end{array}$ & 6 & 66,7 & 3 & 33,3 & 0,394 \\
\hline $\begin{array}{l}\text { Risiko } \\
\text { tinggi }\end{array}$ & 3 & 27,3 & 8 & 72,7 & $\begin{array}{c}\text { (Hubungan } \\
\text { Sedang) }\end{array}$ \\
\hline Total & 9 & 45 & 11 & 55 & \\
\hline
\end{tabular}

tubuh mana yang merasa sakit, pegal, atau nyeri dengan menunjukkan lembar body map yang terbagi menjadi 27 bagian tubuh.

Kemudian pengukurannya dengan menggunakan skoring sebagai tingkat keluhan yang dirasakan menggunakan skala inert yakni skor 0 untuk tidak ada keluhan, skor 1 untuk keluhan yang agak sakit, skor 2 untuk keluhan yang sakit dan skor 3 untuk keluhan yang sangat sakit.

Dari hasil yang diperoleh sebanyak 11 responden yang mengalami keluhan musculoskeletal tingkat tinggi, diantaranya responden yang bekerja pada bagian pembuatan adonan, bagian penggorengan, dan juga packing. Untuk responden dengan keluhan musculoskeletal sedang dialami oleh responden yang bekerja pada penggulungan kulit sumpia.

Pada saat menunjukkan body map kepada responden diselingi dengan wawancara secara informal, hasil wawancara secara informal menunjukkan bahwa rata-rata responden memang mengalami keluhan pada bagian tubuh tertentu seperti punggung, bahu, dsb. Namun ada pula responden yang mengaku tidak mengalami keluhan yang parah karena sudah terbiasa dengan pekerjaannya, sehingga jika terdapat keluhan seringkali diabaikan.

Keluhan musculoskeletal pada responden paling banyak ditemui pada bagian punggung dan bahu bagian kanan.

\section{Sikap Kerja}

Sikap kerja diukur dengan menggunakan Rapid Upper Limb Assessment (RULA) dengan cara pemberian skoring pada bagian tubuh seperti lengan atas, lengan bawah, pergelangan tangan, leher, badan, dan juga kaki. Skor dari bagian tubuh tersebut kemudian akan ditambahkan dengan skor pembebanan dan juga penggunaan otot. Setelah di jumlah maka dapat diketahui apakah sikap kerja responden berisiko atau tidak dengan kategori risiko sangat tinggi, risiko tinggi, risiko sedang, dan risiko rendah.

Hasil penelitian menunjukkan terdapat 9 responden yang memiliki sikap kerja yang berisiko sedang adalah pekerja pada bagian penggulungan sumpia. Diantaranya yaitu responden yang bekerja 11 responden lainnya memiliki sikap kerja dengan risiko tinggi diantaranya pada bagian penggorengan dan pembuatan adonan.

Pemaparan sebelumnya menyebutkan bahwa sikap kerja memiliki 4 kategori, namun pada hasil menjadi dua kategori karena untuk skor 1-4 termasuk dalam kategori sikap kerja risiko rendah, dan untuk skor 5-7 termasuk kategori sikap kerja risiko tinggi. Hal tersebut dilakukan karena untuk mempermudah dalam melakukan analisis data untuk mencari kekuatan hubungan.

Pada penelitian ini responden mengalami sikap kerja statis pada tubuh bagian bawah, dan mengalami sikap kerja yang repetitif pada tubuh bagian atas seperti tangan. Responden melakukan pekerjaan yang repetitif 30 kali dalam satu menit maka berisiko pada bagian tubuh tertentu seperti leher, bahu, dan lainnya. Sikap kerja statis apabila persendian tidak melakukan pergerakan sama sekali.

Hasil analisis menunjukkan sikap kerja memiliki korelasi yang sedang dengan keluhan musculoskeletal. Hal tersebut dapat terjadi karena setiap responden memiliki sikap kerja yang berbeda, misal pada responden yang bekerja membuat adonan kulit sumpia yang banyak menggunakan kekuatan tangan maka berisiko mengalami keluhan pada pergelangan tangan dan juga otot tangan.

Penelitian lain yang dilakukan oleh Bukhori (2010) pada tukang angkut penambang emas di Kecamatan Cilograng Kabupaten Lebak. Pada penelitiannya menunjukkan sikap kerja memiliki hubungan signifikan dengan keluhan musculoskeletal.

Sikap kerja seseorang juga dapat dipengaruhi karena kondisi stasiun kerja yang kurang baik. Banyak responden yang bekerja pada stasiun kerja yang tidak ergonomis. Dapat dilihat pada gambar 1, kursi responden tidak memiliki sandaran punggung, tinggi tempat duduk juga tidak sesuai dengan tinggi siku duduk, selain itu meja yang digunakan juga sangat sempit karena satu meja berukuran $\pm 65 \mathrm{~cm}$ dibagi dua dengan responden lainnya sehingga memiliki meja kerja yang cukup sempit. 
Pada gambar 2 menunjukkan bahwa stasiun kerja responden juga tidak ergonomis karena tinggi tempat duduk yang digunakan tidak sesuai dengan tinggi siku duduk responden. Lebar kursi duduk lebih kecil dari lebar pinggul responden dan juga tidak ada sandaran punggung.

Jika stasiun kerja tidak ergonomis maka dapat menyebabkan posisi kerja juga menjadi berisiko mengalami keluhan musculoskeletal. Oleh karena itu perlu adanya perbaikan stasiun kerja

\section{Hubungan Sikap Kerja dengan Keluhan Musculoskeletal}

Pada hasil penelitian sikap kerja memiliki korelasi yang sedang dengan keluhan musculoskeletal. Hal tersebut sama seperti penelitian yang dilakukan oleh Sihombing (2015) yang menyebutkan bahwa sikap kerja memiliki hubungan yang signifikan dengan keluhan musculoskeletal.

Penelitian yang dilakukan oleh Larono et al. (2017) menunjukkan bahwa sikap kerja memiliki hubungan dengan keluhan musculoskeletal. Penelitian lain dilakukan oleh Suwanto (2016) menyebutkan bahwa terdapat hubungan yang signifikan antara risiko sikap kerja dengan keluhan musculoskeletal.

\section{SIMPULAN}

Berdasarkan penjelasan di atas dapat diambil kesimpulan bahwa korelasi antara keluhan musculoskeletal dengan sikap kerja memiliki nilai korelasi sebesar 0,394. Walaupun sikap kerja memiliki hubungan yang sedang terhadap keluhan musculoskeletal namun bekerja pada posisi yang berisiko tinggi dapat mengalami keluhan musculoskeletal yang tinggi pula.

\section{DAFTAR PUSTAKA}

Akobundu, U., 2008. Hubungan Gangguan Bekerja dengan Musculoskeletal Penyebab dan Pencegahan. Konsultasi Fisioterapi, Hopeville Fisioterapi Klinik, 40 Julius Nyerere Crescent, Asokoro, Abuja.

Alma, B., 2001. Kewirausahaan (Edisi Revisi). Alfabeta: Bandung.

Bird, E.J.F., L. Germain., 2005. Kepemimpinan Pengadilan dan Kerugian Praktis, Edisi ke-3. Terjemahan oleh W. Abdullah. Jakarta: PT. Devnegraha.
Bukhori, E., 2010. Hubungan Faktor Risiko Pekerjaan dengan Terjadinya Keluhan Musculoskeletal Disorders pada Tukang Angkut Beban Penambang Emas di Kecamatan Cilograng Kabupaten Lebak. Skripsi. Jakarta: Universitas Islam Negeri Syarif Hidayatullah.

Elza, D. S., 2012. Gambaran Tingkat Risiko dan keluhan Subjektif Musculoskeletal Disorders pada Pengrajin Songket Tradisional Silungkang Sumatera Barat. Skripsi. Jakarta: Universitas Indonesia.

Evelina, N., 2012. Analisis Tingkat Risiko Ergonomi dan Keluhan Subjektif Musculoskeletal Disorders (MSDs) pada Pengrajin Sepatu di Bengkel Sepatu Tata Kampung Ciomas Bogor Tahun 2012. Skripsi. Depok: Universitas Indonesia.

Grandjean, E., 1993. Fitting the Task to the Man, $4^{\text {th }}$ ed. Taylor and Francis Inc. London.

Ikrimah, N., 2010. Faktor-Faktor yang Berhubungan dengan Keluhan Musculoskeletal Disorders (MSDs) pada Pekerja Konveksi Sektor Usaha Informal di Wilayah Ketapang Cipondoh Tangerang Tahun 2009. Skripsi. Jakarta: Fakultas Kedokteran dan Ilmu Kesehatan Jurusan Kesehatan Masyarakat. Universitas Islam Negeri Syarif Hidayatullah.

Larono, Bella C.D., Odi R Pinontoan., Harvani, B., 2017. Hubungan Sikap Kerja dengan Keluhan Musculoskeletal Disorder pada Pekerja Buruh di Pelabuhan Laut Manado. [e-journal]. Tersedia di https://ejournalhealth.com/index.php/medkes/ article/download/325/317[diakses tanggal 01 Juli 2017]

Maijunidah, E., 2010. Faktor-Faktor yang Mempengaruhi Keluhan Musculoskeletal Disorders (MSDs) pada pekerja Assembling PT. X Bogor tahun 2010. Skripsi. Jakarta: Universitas Islam Negeri Syarif Hidayatullah.

National Institute for Occupational Safety and Health (NIOSH)., 1993. Comment from NIOSH on the Occupational Safety and Health Administration Proposed Rule on Ergonomic Safety and Management US Departement of Control and Service. Diakses pada 02 Agustus 2017 dalam http://www.cdc.gov

Nurmianto, E., 2004. Ergonomi Konsep Dasar dan Aplikasinya. Surabaya: Guna Widya.

Occupational Safety and Health Administration (OHSA) 2000 (Revised). Tersedia di: <https:// www.osha.gov/Publications/osha3125.pdf.>

Riyadina, W., 2008. Cedera Akibat Kerja pada Pekerja Industri di Kawasan Industri Pulo 
Gadung. Majalah Kedokteran Indonesia. 58(5): $148-152$.

Sihombing, A.P., 2015. Hubungan Sikap Ker dengan Musculoskeletal Disorders pada Penjahit di Pusat Industri Kecil Menteng Medan 2015. [e-journal]. Tersedia di https://media.neliti.com/media/ publications/14574-ID-hubungan-sikap-kerjadengan-musculoskeletal-disorders-pada-penjahitdi-pusat-ind.pdf [diakses tanggal 15 Juli 2017]

Suma'mur. 1982. Higiene Perusahaan dan Kesehatan Kerja. Jakarta: PT. Gunung Agung.

Suma'mur., 2001. Keselamatan Kerja dan Pencegahan Kecelakaan. Jakarta: Gunung Agung

Sumiati., 2007. Analisis Risiko Low Back Pain (LBP) pada Perawat Unit Darurat dan Ruang Operasi di RS. Prikasih Jakarta Selatan. Skripsi. Jakarta: Universitas Indonesia.

Suwanto., 2016. Hubungan antara Risiko Postur Kerja dengan Risiko Keluhan Muskuloskeletal Pada Pekerja Bagian Pemotongan Besi di Sentra Industri Pande Besi Padas Klaten. Skripsi. Surakarta: Universitas Muhammadiyah.

Tarwaka., Solichul HA., Bakri., Lilik, S., 2004. Ergonomi untuk Keselamatan, Kesehatan Kerja dan Produktivitas. Surakarta: Uniba Press.

Tarwaka., 2010. Ergonomi Industri. Surakarta: Harapan Press.

Tarwaka., 2014. Ergonomi Industri: Dasar-Dasar Ergonomi dan Implementasi di Tempat Kerja. Surakarta: Harapan Press. 